\title{
A Logotherapeutic Approach to Pastoral Counseling Education for Catholic Seminarians
}

\author{
Joseph R. Laracy ${ }^{1,2,3}$ \\ ${ }^{1}$ Department of Systematic Theology, Seton Hall University, New Jersey, USA \\ ${ }^{2}$ Department of Catholic Studies, Seton Hall University, New Jersey, USA \\ ${ }^{3}$ Department of Mathematics and Computer Science, Seton Hall University, New Jersey, USA
}

Email address:

joseph.laracy@shu.edu

\section{To cite this article:}

Joseph R. Laracy. A Logotherapeutic Approach to Pastoral Counseling Education for Catholic Seminarians. American Journal of Psychiatry and Neuroscience. Vol. 7, No. 2, 2019, pp. 43-51. doi: 10.11648/j.ajpn.20190702.13

Received: May 23, 2019; Accepted: June 20, 2019; Published: July 23, 2019

\begin{abstract}
Viktor Frankl, MD, $\mathrm{PhD}$ is one of the most widely known and highly respected professors of psychiatry and neurology of the twentieth century. In this article, we adapt and apply some of his profound insights for Catholic pastoral counseling education. Pastoral counseling is a very important aspect of the general pastoral formation of Catholic seminarians. The goal of any pastoral counseling course should be twofold. First, it should give seminarians a basic knowledge of mental illnesses to understand their parishioners better. Second, it should offer them concrete techniques to be used in the context of pastoral counseling. Seminary classes in pastoral psychology and counseling sometimes lack a consistent, coherent theoretical foundation, or may attempt to teach techniques inappropriate for use by future parish priests. This paper presents a logotherapeutic approach for the formation of seminarians in pastoral counseling. This approach is congruent with the pastoral sphere as the focus is on meaning and the life of the spirit.
\end{abstract}

Keywords: Logotherapy, Viktor Frankl, Pastoral Counseling, Seminary, Catholic

\section{Preface}

The way in which a man accepts his fate and all the suffering it entails, the way in which he takes up his cross, gives him ample opportunity - even under the most difficult circumstances - to add a deeper meaning to his life. It may remain brave, dignified, and unselfish. Or in the bitter fight for self-preservation he may forget his human dignity and become no more than an animal. Here lies the chance for a man either to make use of or to forgo the opportunities of attaining the moral values that a difficult situation may afford him. And this decides whether he is worthy of his sufferings or not [1].

— Viktor Frankl

\section{Background}

At the beginning of the twentieth century, the predominant priestly formation model in the Catholic Church in the United States was essentially monastic, with relatively little in the way of distinctly pastoral formation. The formational emphasis was on rigorous spiritual and intellectual development, often over an intense, eight year period [2]. However, as early as the 1920s, American Protestants, despite a much briefer clergy formation program, had begun to consider ways to better equip future clergymen in pastoral care, including ministry for those dealing with psychological issues [3]. Richard Clark Cabot, MD, a noted Boston hematologist and social work pioneer, suggested in 1925 that every candidate for the ordained ministry should receive clinical training for pastoral work, analogous to the clinical training offered to medical students [4]. The merits of Dr. Cabot's proposal were soon realized.

The Reverend Anton Theophilus Boisen, a multidenominational clergyman and collaborator of Cabot, helped to form the Council for the Clinical Training of Theological Students in 1930. The goal of the Council was to expose Protestant seminarians for extended periods of time to those suffering from serious illnesses, primarily in psychiatric hospitals [5]. In 1937, the Reformed minister, the Reverend Norman Vincent Peale, DD, and psychiatrist, Smiley 
Blanton, MD, worked together to establish the American Foundation of Religion and Psychiatry, now known as the Blanton-Peale Institute and Counseling Center [6,7].

The Reverend Seward Hiltner, PhD, DD, a Presbyterian minister and a professor at the Princeton Theological Seminary, was another important figure in applying modern psychology to the work of the clergy. His 1949 book, Pastoral Counseling, was the first English language work with that title [8]. Hiltner maintained that "pastoral counseling is only a part of the larger ministry to persons in need of pastoral care." [9] He viewed pastoral counseling as a "functional specialty" in ordained ministry and posited that "the clergymen carrying out this ministry are still, in every fundamental respect, clergymen-representatives of their faith and their religious institutions." [10]

The 1965 promulgation of Optatam Totius by Pope Saint Paul VI was a very significant event in the formation of Catholic priests. The Second Vatican Council's "Decree on Priestly Training" encouraged both the study of the sciences, including psychology, as well as the promotion of "strictly pastoral training." [11] Currently, Catholic seminaries, guided by the fifth edition of the Program of Priestly Formation (PPF), incorporate a substantial amount of dedicated formation in pastoral ministry [12]. In fact, both Catholic and Protestant seminaries often incorporate clinical pastoral education (CPE) in their formation programs. Additionally, seminaries usually have at least one course in pastoral psychology or counseling to introduce future clergy to the scientific study of the human mind and the pastoral application of the clinical principles of mental health.

In a 1966 article in the American Journal of Psychiatry, Bernard L. Pacella, MD, points out that "the techniques used by pastoral counselors bear a similarity to those used by the psychiatrist." However, Pacella wisely notes that "if the pastoral counselor undertakes an interpretive or analytic type of therapy, he steps out of his role as pastor." [13,14] Pacella continues,

If the clergyman-counselor...steps into the role of a behavioral scientist, who must become involved in transference, counter-transference problems, must frequently avoid direct activity in solving current reality problems, must avoid value judgments for the most part, must be an interpreter of unconscious motivations, and must not give direct guidance in critical situations or even spiritual matters...he is no longer a pastor in the meaning which it has for the patient; if he attempts to exercise his role as a clergyman while simultaneously involving himself in interpreting the unconscious, we have quite an unusual situation [15].

Pacella makes a very important distinction. While priests have also been trained as analytic therapists, they are not functioning in a ministerial role while providing that kind of therapy. In this light, how might a Catholic seminarian be best formed in pastoral counseling?

\section{Motivation}

Catholic priests, no matter what their particular assignment at a given time, e.g., parish priest; prison, hospital, or military chaplain; retreat director; high school teacher; university professor; etc.; are frequently engaged in pastoral counseling. Therefore, Catholic seminaries have a compelling interest to form future priests very well in this specific area of ministry. However, it is imperative that the theoretical orientation of the psychological approach be consistent with Catholic theological anthropology.

Every school of psychotherapy rests on what is known as a "theory of personality." These theories orient their respective schools by providing a field of reference to explain and describe human experience. Some of the most common schools of psychotherapy are psychodynamic, behavioral, humanistic, existential, and systemic. While there are aspects of each school that are congruent with Catholic anthropology and other aspects that are not, some are more suitable than others.

The Bible, and specifically the New Testament, offers a distinctive, theological understanding of the human person. The Sacred Scriptures often speak of:

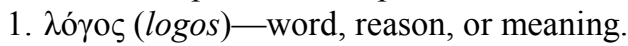

2. $\sigma \tilde{\omega} \mu \alpha$ (soma)-body: the whole organism; the continuity of experience through time.

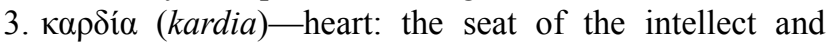
affection.

4. $\sigma \alpha ́ \rho \xi(\operatorname{sarx})$ - [physical] flesh.

5. voũ $\varsigma$ (nous) - mind, also reason or intellect.

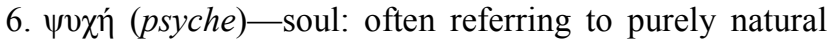
life; root of the word "psychology".

7. $\pi v \varepsilon \tilde{u} \mu \alpha$ (pneuma) - spirit: the principle of which is the Holy Spirit, dwelling and operating in the person.

Catholic theological anthropology is based on these Biblical concepts that describe the human person's different dimensions.

According to Catholic doctrine, the rational soul, directly created by God, is the substantial form of the human body [16]. The Council of Vienne taught this belief de fide in 1311 $[17,18]$. Furthermore, the Church teaches that every human person is made in the image and likeness of God (Genesis 1: 27). Catholics also believe that every human life is unique and special, precious in the sight of God. The Catechism of the Catholic Church states,

God, infinitely perfect and blessed in himself, in a plan of sheer goodness freely created man to make him share in his own blessed life. For this reason, at every time and in every place, God draws close to man. He calls man to seek him, to know him, to love him with all his strength. He calls together all men, scattered and divided by sin, into the unity of his family, the Church. To accomplish this, when the fullness of time had come, God sent his Son as Redeemer and Savior. In his Son and through him, he invites men to become, in the Holy Spirit, his adopted children and thus heirs of his blessed life [19].

Congruent with Catholic thought, Viktor Frankl's anthropology acknowledges all three dimensions of the human person: somatic, psychic, and noetic. He uses the German term Geist, which is often translated in English as 
spirit from the Latin spiritus [pneuma in Greek] to refer to the specifically human dimension of the person. Elaborating his concept of man, Frankl writes,

Three factors characterize human existence as such: man's spirituality, his freedom, his responsibility. The spirituality of man is no epiphenomenon. It cannot be derived from and causally explained by something not spiritual; it is irreducible and indeducible. Spiritual life may very well be conditioned by something, without therefore being caused by it. Normal somatic functions are conditional to the unfolding of spiritual life, but they do not cause or produce it [20].

Like Catholic anthropology, Frankl's logotherapeutic (literally: healing through meaning) approach is rooted in the fact that man must be viewed holistically: body, mind, and spirit $[21,22]$. Frankl's ten theses of the human person can easily be interpreted as very compatible with a Catholic perspective:

1. The person is an individual unity; a person cannot be divided.

2. The person is whole and cannot result from merger; the person cannot be completely fit into non-personal entities such as class or race; the person as such cannot be procreated, it is only the organism that is procreated.

3. The person is absolutely unique.

4. The person is spiritual; this is why the spiritual person is in opposition to the psychophysical organism. The psychophysical organism is a means to a purpose.

5. The person is existential and not material; the person always presently decides who the person may become in the next moment.

6. The person is "I-bound"; the person is not dictated by the psychophysical drives.

7. The person is integrative; the person is the founder of the unity and wholeness of the person (Theses 1 and 2 ); the unity and wholeness of the person is a uniquely personal act.

8. The person is dynamic; that is, the person is able to distance the self from, and to transcend, the psychophysical.

9. The human is not merely an animal because the human is able to self-distance; therefore, the animal cannot be taken as a correlate to the person.

10. The person is a metaphysical entity; the human being understands the self only from the transcendent; the transcendent makes itself known through conscience; the person cannot invent or design the self [23].

The value of a logotherapeutic approach for pastoral counseling is not only in the compatibility with Catholic anthropology but in the following two points:

1. The splendid simplicity of the paradigm; alternatively learning psychodynamic or psychoanalytic therapy requires an in-depth training, which cannot be done in a single course.

2. The paradigm is close to the pastoral sphere as the focus is on meaning and the life of the spirit. Frankl writes that "logotherapy is a psychotherapy of the spiritual." [24] Frankl himself admits that logotherapy was never meant to deal with severe psychosis. However, it has been used to help people with these conditions as well with some degree of success [25].

\section{History and Fundamentals of the Third Viennese School of Psychotherapy}

The logotherapeutic paradigm of Viktor Frankl, MD, PhD (1905-1997) indeed offers a promising psychotherapeutic orientation with many points of continuity with Catholic anthropology and moral theology. Born in Vienna, then the capital of the Austro-Hungarian Empire, Frankl was deeply interested in the fields of medicine, psychology, and philosophy from a very early age. He earned the MD degree from the University of Vienna and then pursued a residency in neurology and psychiatry. Following the Anschluss of Austria by Nazi Germany in 1938, Frankl could no longer work in private practice as a physician. He was however able to take a position as the chief of the Neurological Department of the Rothschild Hospital, a medical center for Jewish patients. During this time, he obstructed numerous Nazi attempted medical murders by making false diagnoses to prevent the euthanasia of mentally ill patients. Due to the overwhelming hopeless feeling of many Jewish people in Austria, Frankl dealt with about ten cases of attempted suicides daily at the Rothschild Hospital. Typical incidents involved overdosing on sleeping pills. Frankl developed a technique to administer stimulants intravenously, and when necessary, intracisternally, i.e., directly into the cerebrospinal fluid of the brain ventricles by suboccipital brain puncture. Despite not being originally trained as a neurosurgeon, out of necessity, Frankl developed a technique to drill into the skull, administering medication directly in the side ventricle, while draining the fourth ventricle with a suboccipital puncture. In doing so, he saved many patients who would have otherwise succeeded in their attempted suicides [26].

In 1942, the Nazis arrested Frankl, his wife, his parents, and many other Austrian Jews and deported them to concentration camps. His wife and parents did not survive. Viktor survived four camps, including Auschwitz. US soldiers liberated Frankl and his fellow prisoners from Türkheim, a subcamp of Dachau, in April 1945 [27]. Frankl immediately returned to his work as a neurologist and psychiatrist, attending to many patients suffering in body, mind, and spirit as a result of the Second World War. From 1946-1971 he served as chief of the Neurological Department of the Polyclinic in Vienna. In 1946, Frankl published what would become his most famous book,...trotzdem Ja zum Leben sagen: Ein Psychologe erlebt das Konzentrationslager, later released in English as Man's Search for Meaning. Man's Search for Meaning has been translated into at least 24 languages and more than 12 million copies have been sold. During this period, Frankl also 
worked toward a doctorate in philosophy, focusing on the philosophy of religion, which he earned in 1948. His dissertation was published as a book, Der Unbewußte Gott. It was later released in English as The Unconscious God: Psychotherapy and Theology [28]. Frankl was granted a professorship in neurology and psychiatry at the University of Vienna in 1955. Over the course of his lifetime, Professor Frankl authored thirty-nine books, now available in fifty languages [29].

One of Frankl's greatest honors was an invitation to a private audience with Pope Paul VI. He and his wife, Elly, a practicing Catholic, were deeply impressed by their encounter with now Saint Paul VI. Frankl told Pope Paul:

While others may look at what I may have accomplished, or rather, at which turned out well by good fortune, I realize at such moments how much more I should have done, but failed to do. In other words, how much do I owe to God's grace, granted to me for all these years beyond the time I was forced to walk through the gates of Auschwitz [30].

In his autobiography, Frankl recounts how the Holy Father acknowledged the significance of logotherapy for the Catholic Church and for all humankind... [and at] the end of the audience... he suddenly began to speak in German once again, calling after us - to me, the Jewish neurologist from Vienna-in exactly these words: "Please pray for me!" [31]

Well aware of the very significant contributions of Sigmund Freud, MD and Alfred Adler, MD, Frankl disagreed profoundly with their psychodynamic theoretical orientations and clinical approaches [32]. According to Freud, the drive for pleasure, particularly sexual pleasure, was the dominant force in the human psyche and the repression of this drive is a primary cause of neurosis (transference often offering a possible cure) [33]. This view is a tenet of the first Viennese school of psychotherapy-Freudian psychoanalysis [34,35]. Adler, initially a student and later colleague of Freud, eventually parted ways with his mentor. Friedrich Nietzsche's theory of the will to power (der Wille zur Macht) was very compelling to Adler. Adler would eventually posit that the drive for power, not pleasure, was the key to understanding the human person. This presupposition is a pillar of the second Viennese school of psychotherapy-Adlerian individual psychology [36].

By contrast, Frankl's hypothesis, confirmed by his experience in Nazi camps, is that the strongest force in man is the will to meaning [37]. Frankl explains that meaning is something that is discovered, rather than produced, and can be encountered through experiential, creative, or attitudinal values. Frankl describes the three types of values in this way:

What are the possibilities for giving life meaning, for realizing values? There are several answers Men can give meaning to their lives by realizing what I call creative values, by achieving tasks. But they can also give meaning to their lives by realizing experiential values, by experiencing the Good, the True, and the Beautiful, or by knowing a single human being in all his uniqueness. But even a man who finds himself in the greatest distress, in which neither activity nor creativity can bring values to life, nor experience give meaning to it-even such a man can still give his life a meaning by the way he faces his fate, his distress. By taking his unavoidable suffering upon himself he may yet realize values. Thus, life has meaning to the last breath. For the possibility of realizing values by the very attitude with which we face our unchangeable suffering - this possibility exists to the very last moment. I call such values attitudinal values. The right kind of suffering-facing your fate without flinching-is the highest achievement that has been granted to man [38].

Despite the fact that Frankl and the other prisoners were largely unable to realize the desire for pleasure or the desire for power during their confinement, the Nazis guards were unable deprive them of sources of meaning. Victims of Nazi camps were still able to discover meaning in a person to love, perhaps a spouse in another camp or who escaped capture (experiential), a cause to serve, such as a religious mission to fellow prisoners (creative), or a courageous stance toward unavoidable suffering from starvation, disease, and torture (attitudinal). Interestingly, Frankl observed that those prisoners who fell into despair from a lack of meaning in their lives would often, in a matter of days, develop a serious somatic illness, such as typhus. Frankl astutely observed that "the sudden loss of hope and courage can have a deadly effect." [39]

As a professor of neurology and psychiatry, Frankl developed an exhaustive classification of mental disorders [40]. In this context, he introduced a new and very important classification: noogenic neuroses [41]. This type of neurosis is a mental illness caused by a spiritual or existential crisis, e.g., adjustment disorder with depressed mood in reaction to a divorce [42]. Frankl's framework accounts for emotionalpsychological manifestations and symptoms that are rooted in a problem of meaning, i.e., a spiritual-existential origin. This is precisely in the sphere of the Catholic priest when called upon to provide pastoral counseling. Other theorists dealing with psychological problems do not directly engage these causal factors of symptoms.

The three hallmark techniques employed in logotherapy: paradoxical intention, dereflection, and Socratic dialogue, are also consistent with scope and aims of pastoral counseling in a Catholic ministerial context. Paradoxical intention is a technique that takes advantage of one of the most human activities, humor. With this technique, Frankl intensified a patient's emotional state in order to help him understand the irrationality of an emotional reaction. Frankl developed this technique to treat phobic and obsessivecompulsive disorders. For example, it may happen that a man suffering from hyperhidrosis may develop hydrophobia. A neurotic fear of sweating in public provokes hydrophobia and the hydrophobia reinforces the hyperhidrosis. To break the neurotic cycle, Frankl encouraged the patient to "paradoxically" will to sweat more than he has ever sweat before, to show the world what a great sweater he is. In doing so, the patient began to laugh and the absurdity of the suggestion allowed him to gain distance and eventually 
freedom from the phobia [43].

Dereflection is a logotherapeutic technique utilized when a patient is overly self-absorbed with a goal. Frankl found that by redirecting the attention, or "dereflecting" the attention away from oneself, the patient could achieve inner peace and often succeed in accomplishing his goal. This technique is especially useful for patients suffering from hyper-reflection and compulsive self-observation. For example, a married man may become impotent as a result of hyper-intending the pleasure of his wife in the marital act; the more he thinks about his potency during the act, the less likely he may be able to achieve it. In these cases, Frankl would ask the patient to abstain from relations with his wife. After some days of obedience to the doctor, the man's natural desire for physical intimacy would lead him to return to attempting marital relations, but this time able to give himself in the act, free from hyper-reflection, and succeed in marital intercourse [44].

Finally, Socratic dialogue is a logotherapeutic technique in which Frankl used the patient's own words as a method of self-discovery. By listening intently to what patients said, Frankl could point out specific patterns of words, or "word solutions" to patients, and allow the patients see new meaning in them. This process often brings about a "modification of attitudes" and allow a patient to discover the answer to his problem. Frankl's use of Socratic dialogue often involved specific questions aimed at helping the patient to acknowledge the freedom to fulfill meaning in his life [45]. As James M. DuBois, PhD, DSc puts it, "A patient's voice of conscience (the power to discern one's unique meaning) is often heard in dialogues." [46]

In a recent review article on the clinical applications of logotherapy and Frankl's legacy, Girmenia et al. show how Frankl's thought has found wide application in many areas, not limited to patients in a neuropsychiatric hospital ward [47]. They write,

We must not forget how logotherapy has been put at the disposal of the sufferer in its broadest sense. Especially in the context of care and care of the chronically ill (e.g., cancer, heart disease, degenerative diseases, etc.)...The rehumanization of the relationship of care, the search for a meaning to give to one's own experience of illness, the distance from the symptoms, the rediscovery of the deepest spiritual meanings, are topics that have made logotherapy one of the main instruments of support to the patient, above all to the gravely or chronically ill patient, to whom we cannot give answers exclusively of a somatic type [48]. (Author's translation from the Italian)

Laracy and Kelly suggest how Frankl's writings may contribute toward a general renewal of patient care, forming future physicians to view patients in a more holistic way: body, mind, and spirit [49]. This perspective is consistent with the innovations in the theory and practice of medicine initiated by Andrew T. Still, MD, DO.

How can Frankl's insights be concretely communicated to future priests destined for pastoral counseling?

\section{Outline of a Possible Logotherapeutic Course in Pastoral Counseling}

The applicability of Frankl's insights in an explicitly Christian pastoral setting has been well established. Donald F. Tweedie, Jr., $\mathrm{PhD}$, a professor of psychology at Fuller Theological Seminary, conducted one of the first studies. He is the author of Logotherapy and the Christian faith: An Evaluation of Frankl's Existential Approach to Psychotherapy [50]. The Reverend Robert C. Leslie, PhD, a Methodist pastor and professor of pastoral psychology and counseling at the Pacific School of Religion, Berkeley, attempted to explicate how Jesus characteristically worked with suffering people. He examined eleven well-known encounters between Jesus and various Gospel figures and analyzed Jesus' approach within the perspective of logotherapy [51]. More recently, Ann Graber, DMin, $\mathrm{PhD}$ has demonstrated the effectiveness and ecumenical suitability of logotherapy for those in pastoral ministry. She validated how existential analysis can be both scientifically sound and theologically grounded [52]. The author finds her approach particularly helpful. Marie S. Dezelic, $\mathrm{PhD}$ and Gabriel Ghanoum, PsyD have recently published a book that offers an eight-session protocol which allows clinicians and facilitators to follow a manualized format to assist in existential exploration and personal growth. They offer insights applicable across clinical therapeutic settings and spiritual centers [53].

A logotherapeutic course in pastoral counseling for Catholic seminarians should begin with the students reading Frankl's magnum opus, Man's Search for Meaning. The seminarians would be expected to write a 1,000 word "book review" to demonstrate their comprehension of the material. A sequence of fourteen lectures, two and a half to three hours long is proposed. The lectures on the neurobiological basis of mental illness and psychiatric medications obviously require highly specialized, scientific expertise. It is envisioned that a neuropsychologist, neuroscientist, or physician would teach the neurobiological lecture. A physician would certainly be asked to teach the lecture on psychiatric medications.

1. Historical Overview: Historical outline of psychiatry; Twentieth century schools of psychotherapy; The milieu of Vienna in which Freud, Adler, and Frankl lived.

2. Life and Work of Dr. Viktor Frankl: Biographical information on Frankl; Foundational aspects of existential analysis (logotherapy).

3. Philosophical Foundations of Franklian Theories: Greek philosophy; German Enlightenment; Existentialism; and Phenomenology (e.g., Max Scheler's Hierarchy of Values); Critical engagement from a Catholic perspective.

4. Fundamental Logotherapeutic Concepts: Franklian terminology; Freedom of Will; Will to Meaning; Meaning of Life; Dimensions of human existence (anthropology); Ways of Discovering Meaning (Creative, Experiential, Attitudinal); Tragic Triad (Guilt, Suffering, and Death).

5. Logotherapy and Religion: Psychology and Religion; 
Frank's position on religion; Logotherapy's compatibility with religion; Frankl's ten theses on the human person; Clinical vs Pastoral settings; Basic Counseling Skills: active listening, asking open questions, giving verbal empathy, summarizing what the counselee has said regarding their problem, etc.

6. Frankl's Theory of Mental Illness: Ontology $\rightarrow$ Etiology $\rightarrow$ Classification $\rightarrow$ Therapy; Endogenous Psychoses, Psychosomatic Illnesses, Functional Neuroses, Reactive Neuroses, Iatrogenic Neuroses, Psychogenic Neuroses, Noogenic Neuroses, Societal Neuroses; Relationship to DSM.

7. Neurobiological Basis of Mental Illness: Fundamental biological psychology and overview of the structure and function of the human nervous system from the molecular to systemic level; Overview of the factors that distinguish traditionally "neurological" diseases from traditionally "psychiatric" diseases, e.g., neuroimaging distinctions.

8. Psychiatric Medications: Awareness of the pharmaceutical treatments prescribed by physicians (e.g., antidepressants, antipsychotics, anxiolytics, depressants, mood stabilizers, stimulants); Overview of effectiveness as well as side effects and possible complications.

9. Dereflection Technique: Principle of SelfTranscendence; Illustrative examples of the technique; Practicum.

10. Paradoxical Intention Technique: Principle of SelfDistancing; Illustrative examples of the technique; Practicum.

11. Socratic Dialogue Technique: Principle of SelfAwareness; Illustrative examples of the technique; Practicum.

12. Ministerial Scenarios I: Discussion of common pastoral situations: Bereavement; Marriage Difficulties; Existential Crisis; Depression; Anxiety.

13. Ministerial Scenarios II: Discussion of pastoral situation of substance abuse: Marijuana, Alcohol, Opioids, Psychedelics, CNS stimulants, CNS depressants.

14. Working with Mental Health Professionals | Conclusion: Referrals to psychiatrists, primary care physicians, clinical psychologists, counseling psychologists, school psychologists, licensed clinical social workers, licensed professional counselors, licensed marriage and family therapists, and psychiatric nurse practitioners; Confidentiality (ecclesial and legal); The role of the experience of beauty in psychotherapy [54]; Awareness and merit of other paradigms of clinical praxis, e.g., CBT; Final Remarks.

The student's grade would be based on their book report $(20 \%)$, class attendance and participation $(30 \%)$, and a final comprehensive oral examination (50\%).

The following works by Frankl, all available in English, would be included in the course syllabus bibliography, and constitute the primary sources for the lectures.

1. Man's Search for Meaning (2006): Frankl's magnum opus originally published in 1946

2. The Doctor and the Soul: From Psychotherapy to Logotherapy 3rd edition (1986): A manuscript started before WWII, destroyed in a Nazi concentration camp, re-written from memory while still in the concentration camps, and finally published after Frankl's liberation in 1946.

3. Man's Ultimate Search for Meaning (2000): Material drawn from a lecture given in 1947 in Germany.

4. On the Theory and Therapy of Mental Disorders: An Introduction to Logotherapy and Existential Analysis $8^{\text {th }}$ edition (2004): A psychiatric manual, originally published in 1956, which systematically presents Frank's approach to treating mental illness.

5. The Will to Meaning: Foundations and Applications of Logotherapy (1988): Collection of lectures given in 1966 at Perkin's School of Theology at Southern Methodist University.

6. The Unheard Cry for Meaning: Psychotherapy and Humanism (1978): Combination of papers and new material further developing ideas since his $\mathrm{PhD}$ dissertation.

7. Recollections: An Autobiography (2000): Frankl's reflection on his life, published in 1995 in German to coincide with his $90^{\text {th }}$ birthday.

8. The Feeling of Meaninglessness: A Challenge to Psychotherapy and Philosophy (2010): A collection of important conference and journal papers by Frankl.

\section{Conclusion}

The integration of modern psychological principles and methods with traditional ministerial training to equip future Catholic priests to better address the psycho-spiritual issues of the people entrusted to their pastoral care must be a priority for seminaries. The principles and methods of Viktor Frankl-logotherapy_offer an attractive paradigm for training future priests in the important ministry of pastoral counseling. A logotherapeutic course, as outlined above, has the potential to give future priests both the theoretical and practical knowledge to better serve the people of God suffering in mind, body, or spirit.

\section{Dedication}

This research is dedicated to the memory of the Reverend Robert Blyman, MD (1945-2019), a priest of the Diocese of Rockville Centre, NY. Father Blyman was an extraordinary pastor, psychiatrist, and seminary formator.

\section{Conflict of Interest Statement}

The author declares that he has no conflict of interest.

\section{Acknowledgements}

The author is very grateful for the assistance with this 
research as well as helpful comments on earlier drafts of this article from Michael D. Kelly, DO; Simón Espinosa Olarte, MSc; Sister Marysia Weber, RSM, DO; the Reverend Thomas K. Macdonald, STD; the Reverend Daniel R. Peterson, MDiv, MA; Margaret R. Laracy, PsyD; the Reverend John Burns, STD; and the anonymous reviewers. The author also acknowledges the support of the Reverend Monsignor Richard Liddy, $\mathrm{PhD}$ and the Center for Catholic Studies at Seton Hall University.

\section{References}

[1] Viktor E. Frankl, Man's Search for Meaning, trans. Ilse Lasch (Boston: Beacon Press, 2006), 67.

[2] The typical sequence after high school for Catholic seminary was four years of Neo-Scholastic Thomistic philosophy and classical languages (Latin, Greek, and Hebrew) followed by four years of systematic theology, moral theology, canon law, church history, spiritual theology, etc.

[3] Following a BA degree, typically in liberal arts, the Protestant mainline seminary experience was traditionally a three year course of theological study leading to a Bachelor of Divinity (BDiv). In the second half of the twentieth century, American Divinity schools would rename this graduate professional degree as the MDiv.

[4] Richard C. Cabot, "Adventures on the Borderland of Ethics: A Plea for a Clinical Year in the Course of Theological Study," The Survey Graphic 55, no. 5 (December 1, 1925): 275-277.

[5] Curtis W. Hart, "Anton Boisen: Madness, Mental Health and the Ministry," Journal of Religion, Disability \& Health 1, no. 2 (1994): 60-62.

[6] It must be mentioned that the Reverend Dr. Peale was a very controversial figure in Christianity and politics. On September 7, 1960 Peale, representing 150 largely anonymous Protestant clergymen, publically opposed the election of John F. Kennedy as president on religious grounds. Peale famously stated "our American culture is at stake" if a Catholic were elected to the Presidency. "The Power of Negative Thinking," Time, September 19, 1960, 22. Peale and his group declared that Kennedy would serve the interests of the Catholic Church over the interests of the United States, writing, "It is inconceivable that a Roman Catholic president would not be under extreme pressure by the hierarchy of his church to accede to its policies with respect to foreign interests." "The Religious Issue: Hot and Getting Hotter," Newsweek, September 19, 1960, 38. Peale and his collaborators even went so far as to posit that the election of a Catholic could end free speech in the United States. California Episcopal Bishop, the Right Reverend James Pike, JSD, not known for his sympathy for Catholic causes, responded stating, "Any argument which would rule out a Roman Catholic just because he is Roman Catholic is both bigotry and a violation of the constitutional guarantee of no religious test for public office." "The Power of Negative Thinking," 22. The Reformed tradition ethicist and theologian, the Reverend Reinhold Niebuhr, highlighted the fact that "Dr. Peale and his associates... show blind prejudice." "The Religious Issue: Hot and Getting Hotter," 38. Peale's position was also condemned by former President Harry Truman and a broad spectrum of religious leaders, Jewish and Christian. He eventually recanted his statements. Independent of the Kennedy incident, Peale's best-selling self- help book, The Power of Positive Thinking, was also the subject of substantial theological critique from his fellow Protestant clergymen and theologians Norman Vincent Peale, The Power of Positive Thinking (New York: Prentice-Hall, 1952). For example, the Reverend Liston Pope, PhD, Dean of Yale Divinity School, is cited stating, "There is nothing humble or pious in the view this cult takes of God. God becomes sort of a master psychiatrist who will help you get out of your difficulties. The formulas and the constant reiteration of such themes as 'You and God can do anything' are very nearly blasphemous." William Peters, "The Case against Easy Religion,” Redbook Magazine, September 1955, 92.

[7] "Blanton-Peale Institute and Counseling Center," About Us, last modified 2018, accessed February 28, 2019, http://www.blantonpeale.org/about_us.html.

[8] Seward Hiltner, Pastoral Counseling (Nashville, TN: Abingdon Press, 1949).

[9] Bernard L. Pacella, "A Critical Appraisal of Pastoral Counseling," American Journal of Psychiatry 123, no. 6 (December 1966): 650.

[10] Pacella, 651.

[11] Second Vatican Council, Optatam Totius, 1965, chap. 6.

[12] USCCB, Program of Priestly Formation, 5th ed. (Washington, DC, 2005), accessed March 1, 2019, http://www.usccb.org/ upload/program-priestly-formation-fifth-edition.pdf.

[13] Dr. Pacella refers to an "analytic type of therapy" because he was trained in psychoanalysis and practiced that form of psychotherapy.

[14] Pacella, "A Critical Appraisal of Pastoral Counseling," 646.

[15] Pacella, 649.

[16] In Aristotelian-Thomistic metaphysics, the form of a thing is the principle of its material organization. A substantial form "informs" prime matter and thereby brings into existence a new substance. For more information, see Aquinas' Summa Theologice, I, Q 76, A 1.

[17] De fide (of the faith) is a "theological note" indicating that a doctrine is classified as an essential part of Catholic faith and that denial of it is heresy.

[18] Council of Vienne, "Decrees," in Decrees of the Ecumenical Councils, ed. Norman P. Tanner, vol. 1, 2 vols. (Washington, DC: Georgetown University Press, 1990).

[19] Catechism of the Catholic Church, 2nd ed. (New York: Double Day, 2003), para. 1.

[20] Viktor E. Frankl, "The Concept of Man in Psychotherapy," Proceedings of the Royal Society of Medicine 47, no. 11 (June 15, 1954): 979.

[21] It is important to note that logos, in the original, classical context, signified not just "meaning." Logos encompassed all four Aristotelian causes (e.g., material, formal, efficient, and final). The Enlightenment's dismissal of final causality, i.e., telos, can imply a reductive notion of "meaning" that is problematic from a Catholic theological perspective.

[22] Viktor E. Frankl, On the Theory and Therapy of Mental Disorders: An Introduction to Logotherapy and Existential Analysis, 8th ed. (New York: Routledge, 2004). 
[23] Viktor E. Frankl, "The Unconditional Human: V. E. Frankl's Meta-Clinical Lectures," trans. Willem J. Maas (University of Salzburg, 1950: Unpublished Translation, 2001).

[24] Frankl, On the Theory and Therapy of Mental Disorders, 64.

[25] Frankl, chap. 2.

[26] Viktor E. Frankl, Recollections: An Autobiography, trans. Joseph Fabry and Judith Fabry (Cambridge, MA: Basic Books, 2000), 76-79.

[27] "Viktor Frankl: Life and Work," Viktor Frankl Institute, University of Vienna, last modified 2019, accessed March 5, 2019, https://www.univie.ac.at/logotherapy/lifeandwork.html.

[28] Viktor E. Frankl, The Unconscious God: Psychotherapy and Theology (New York: Simon and Schuster, 1975).

[29] "Viktor Frankl: Life and Work."

[30] Frank1, Recollections: An Autobiography, 124.

[31] Frankl, 125.

[32] Viktor E. Frankl, Man's Search for Ultimate Meaning (Cambridge, MA: Basic Books, 2000), 25-29.

[33] Classical psychoanalytic treatment sessions typically occur 45 times a week and last about an hour. The analyst asks the patient to expresses his thoughts freely, i.e., the method of free association. The patient then shares whatever comes to mind, including fantasies and dreams. The analyst then has the challenging of inferring the unconscious conflicts causing the patient's neurosis and interpreting the transference (and countertransference, i.e., the analyst's feelings for the patient). Transference (Übertragung) is a phenomenon posited by Freud and characterized by an unconscious projection of the feelings, e.g., rage, attraction, dependence, etc., a patient has about someone, e.g., one's father, on to the psychotherapist. A primary goal of psychoanalytic therapy is to reveal the unconscious content of a patient's mind in an effort to alleviate "psychic tension." For more details, see Sigmund Freud, A General Introduction to Psychoanalysis (New York: Boni and Liveright, 1920).

[34] Sigmund Freud, The Ego and the Id, trans. Joan Riviere (London: Hogarth Press and the Institute of Psychoanalysis, 1927).

[35] It is interesting to note that starting about forty years ago, the popularity of Freud's psychoanalytic model among practicing psychiatrists greatly declined as more effective psychiatric drugs became available. "Reductionist biologism" became the dominant paradigm. Niall McLaren, MBBS writes, "There was a revolution in psychiatry as the psychoanalytic model passed quickly from the scene to be replaced by a rigid biological reductionism. In a few years, the Freudian theories, which had so dominated academic and private psychiatry for half a century or more, disappeared from curricula all over the country. The many institutes of psychoanalysis lost their students and their prestige. Equally quickly, psychoanalytically oriented psychiatry lost its funding as insurers and governments swung behind the confidently expressed diagnostic and therapeutic power of the burgeoning biological movement. With the publication of the American Psychiatric Association's Diagnostic and Statistical Manual of Mental Disorders ( $3^{\text {rd }}$ ed.) (DSM-III) in 1980, the revolution was complete." Niall McLaren, "Toward an Osteopathic Psychiatry: The Biocognitive Model of Mind," The Journal of the American Osteopathic Association 110, no. 12 (December
1, 2010): 726. Joel Paris, MD contends that "(psycho) analysis has separated itself from psychiatry and psychology by teaching its method in stand-alone institutes. The field may only survive if it is prepared to dismantle its structure as a separate discipline and rejoin academia and clinical science. Whatever its limitations, psychoanalysis left an important legacy to psychiatry. It taught a generation of psychiatrists how to understand life histories and to listen attentively to what patients say. In an era dominated by neuroscience, diagnostic checklists, and psychopharmacology, we need to find a way to retain psychotherapy, whose basic concepts can be traced back to the work of Freud, as part of psychiatry." Joel Paris, "Is Psychoanalysis Still Relevant to Psychiatry?" Canadian Journal of Psychiatry 62, no. 5 (May 2017): 312.

[36] Alfred Adler, The Neurotic Constitution: Outlines of a Comparative Individualistic Psychology and Psychotherapy, trans. John Edward Lind and Bernard Glueck (New York: Moffat, Yard and Company, 1917).

[37] The "will to meaning" could be understood in diverse ways and there is some ambiguity in Frankl's use of the concept. A reception of the theory consistent with Catholic thought would surely reject certain philosophical interpretations. For example, Catholics cannot accept an interpretation that would carry David Hume's "fact-value distinction." Hume conjectures that man is unable to ground normative arguments in positive arguments - to derive ought from is. In addition, Catholics would fervently argue against Friedrich Nietzsche's proposal that moral values are completely arbitrary and the "willing" or "creating" them is the most important thing, i.e., the act of valuing is more important than the content of the values. Friedrich Nietzche, Thus Spoke Zarathustra, trans. Graham Parkes (Oxford, UK: Oxford University Press, 2009). The will to meaning can be understood as the human aspiration to discover God's blessings in one's life in the gifts and talents bestowed, the love offered by Him and fellow men and women, and the grace available to endure unavoidable suffering recalling the redemptive example of the Lord.

[38] Viktor E. Frankl, The Doctor and the Soul: From Psychotherapy to Logotherapy, trans. Richard Winton and Clara Winton, 3rd ed. (New York: Vintage, 1986), xix.

[39] Frankl, Man's Search for Meaning, 75.

[40] His classification schema includes endogenous psychosesmental diseases with a somatic cause (e.g., major depressive disorder), psychosomatic illnesses-physical illnesses triggered by psychological factors but not caused by them (e.g., asthma), organ neuroses - diseases caused by psychological factors that falsely appear to be caused by a somatic condition (e.g., conversion disorder), pseudo-neuroses - mental illnesses caused by biological factors but that falsely appears to be brought about by a psychological cause (e.g., masked hypocorticalism), reactive neuroses - mental illnesses caused by a psychological reaction to the effects of a disturbance, either psychological or physiological (e.g., phobic fear of sweating arising from anticipatory anxiety), personality disorders - constitutional traits that are similar to neurotic traits (e.g., obsessive-compulsive disorder), iatrogenic neurosespsychological disorders caused or worsened by a psychological intervention (e.g., phobic fear of psychosis due to a psychiatrist's failure to explain a diagnosis), psychogenic neuroses - mental disorders with a psychological cause (e.g., tic disorder in reaction to a stressful work situation), collective neuroses - pandemic unhealthy attitudes that exert a social influence (e.g., fatalism). See Frankl, On the Theory and Therapy of Mental Disorders, xviii-xix. 
[41] Frankl and some other European psychiatrists estimate that $20 \%$ of neuroses are noogenic. See Viktor E. Frankl, The Feeling of Meaninlessness: A Challenge to Psychotherapy and Philosophy (Milwaukee: Marquette University Press, 2010), 126.

[42] Frankl, On the Theory and Therapy of Mental Disorders, xxxi.

[43] Frankl, 108.

[44] Frankl, 32-36.

[45] Ann V. Graber, Viktor Frankl's Logotherapy: Method of Choice in Ecumenical Pastoral Psychology, 2nd ed. (Lima, OH: Wyndham Hall Press, 2004), 113-117.

[46] Frankl, On the Theory and Therapy of Mental Disorders, xxxv.

[47] Enrico Girmenia, Laura Andrissi, and Vittoradolfo Tambone, "Sulle applicazioni cliniche della logoterapia: una rassegna sull'eredità di Victor Emil Frankl," La Clinica Terapeutica 165, no. 4 (2014): 330-335.

[48] Girmenia et al., 330.

[49] Joseph R. Laracy and Michael D. Kelly, "Toward a Renewal of Patient Care: Insights from Viktor Frankl, MD, PhD,"
Journal of the American Osteopathic Association 118, no. 5 (May 2018): 293-295.

[50] Donald F. Tweedie, Jr., Logotherapy and the Christian Faith: An Evaluation of Frankl's Existential Approach to Pschotherapy (Grand Rapids, MI: Baker Book House, 1961).

[51] Robert C. Leslie, Jesus and Logotherapy: The Ministry of Jesus as Interpreted through the Psychotherapy of Viktor Frankl (New York: Abingdon Press, 1965).

[52] Graber, Viktor Frankl's Logotherapy.

[53] Marie S. Dezelic and Gabriel Ghanoum, Meaning-Centered Therapy Manual: Logotherapy \& Existential Analysis Brief Therapy Protocol for Group \& Individual Sessions (Miami, FL: Presence Press International, 2015).

[54] Here we intend to present a philosophical framework for understanding beauty as well as a conception of the human person that can embrace the whole scope of beauty's effects. This account of beauty is linked to psychological health rooted in a biopsychosocial-spiritual model of the human person. See Margaret R. Laracy, "The Role of the Experience of Beauty in Psychotherapy" (PsyD, Institute for the Psychological Sciences, 2011). 